357; lower section of basal nervure (not allowing for curve) 595; basal nervure apicad of transverso-medial $5 \mathrm{I}$; basal side of first submarginal cell $\mathrm{I} 87$, its lower side 73I, its diameter measured from lower basal to upper apical corners 8I6; transverse (radial) diameter of second submarginal cell 187 , its side on first discoidal I70; lower side of third submarginal 425 ; insertion of first to insertion of second recurrent nervures 374 .

Hab.-Miocene shales of Florissant, igo8. In my table of Florissant bees (Bull-Mus. Comp. Zool. I906) this runs to Halictus florissantellus, from which it differs by the broader, reddish abdomen; the light reddish nervures and stigma; the transversomedial separated from the basal nervure by a short interval, etc.

\title{
Two New Species of Coccinellidae (Coleoptera).
}

By F. W. Nunenmacher, Piedmont, Calif.

While working over some material collected near Goldfield, Nev., during the last year, I found two Coccinellidæ which I consider belong to undescribed species. I therefore take this opportunity to make them known.

\section{Coccinella vandykei n. sp.}

Oval, strongly convex. Head, black, finely punctate, with two yellow spots on vertex. Thorax, black, shining, a little more coarsely punctured than the head, and with a quadrate yellow spot at each anterior angle. Elytra, bright red, finely but thickly punctured, and together marked with seven black spots. These latter are arranged as follows: A common large scutellar spot, and on each elytron, a small median one near the margin, a larger discoidal close to the suture, and a third large spot, more oblong than round or oval, placed subapically and closer to the margin than the suture. Under side black, the mesosternal epimeron and the metasternal epimeron yellow, moderately coarsely punctured throughout. L. .I8 to .20 inch; w. .I4 to .I6.

Scarce, on sage brush at 6600 feet elevation Goldfield, Nev., VI, 29, 'O7.

I consider this species a form intermediate between C. 9notata and $C$. californica, resembling the first most with regard to the elytral markings, and the latter most with regard to the markings of the head and thorax. The scutellar spot, with regard to its size and form, also more closely resembles that on C. californica than that on C. 9-notata. 
With careful collecting in the northern parts of Nevada, I believe that forms might be discovered with characters so intermediate that we would be compelled to reduce this species to a variety of $C$. 9-notata. So far no connecting links have been discovered.

\section{Brachyacantha blaisdelli n. sp.}

Oblong, not very convex. Head, yellow in the $\hat{o}$, black in the $q$ and with a large yellow spot placed vertically, shining, finely but thickly punctured with very shallow punctures. Thorax of $\hat{o}$, black, slightly more heavily punctured than the head, a broad yellow patch laterally, and with front and side margins lined with a narrow pale or whitish yellow band. Thorax of $q$, black, punctured as in the male, with a broad yellow patch laterally but with light marginal band only found on the side margins and ending abruptly at the front angles. Elytra, black, shining, the punctures the same as on the thorax. Each elytron with a fascia and a sub-apical spot. The fascia is placed in front of the middle, is narrowest at its outer part where it touches the margin, but on the inner edge, is dilated into an irregular rounded blotch which does not quite reach the suture and which gives off a spur that runs parallel with the suture until it joins the sub-apical spot thus forming a sort of vitta. The confluence of the spur with the sub-apical spot is found in the $o$ but not in the $\hat{b}$. Under side of thorax yellow; not strongly punctured; of body, black; femur, dark; knees, tibia, and tarsi testaceous. L. .I8 to .20 in inch; w. I2 to .I5.

Description based upon $\hat{o}$ and $q$ taken at Goldfield, Nev., VI, 29, '07, by the author. Have also several other specimens from same locality and have seen several specimens taken by Dr. F. E. Blaisdell, at Mesa Grande, Sonoma Co., Calif., and one taken by Mr. F. C. Clark at Napa, Calif.

This species is closely related to $B$. dentipes Fab, but can be readily separated from it by the following characters: the form more narrow and less convex, by $B$. dentipes, having the markings of the front and sides of the thorax of the same color, orange, while $B$. blaisdelli has them of a different color, and with the front margin narrower. The tubercles in B. blaisdelli are more prominent and with a greater space between them; the fourth, fifth and sixth ventral segments are depressed, and the spine of the anterior tibia is not so strongly developed as it is in B. dentipes. 


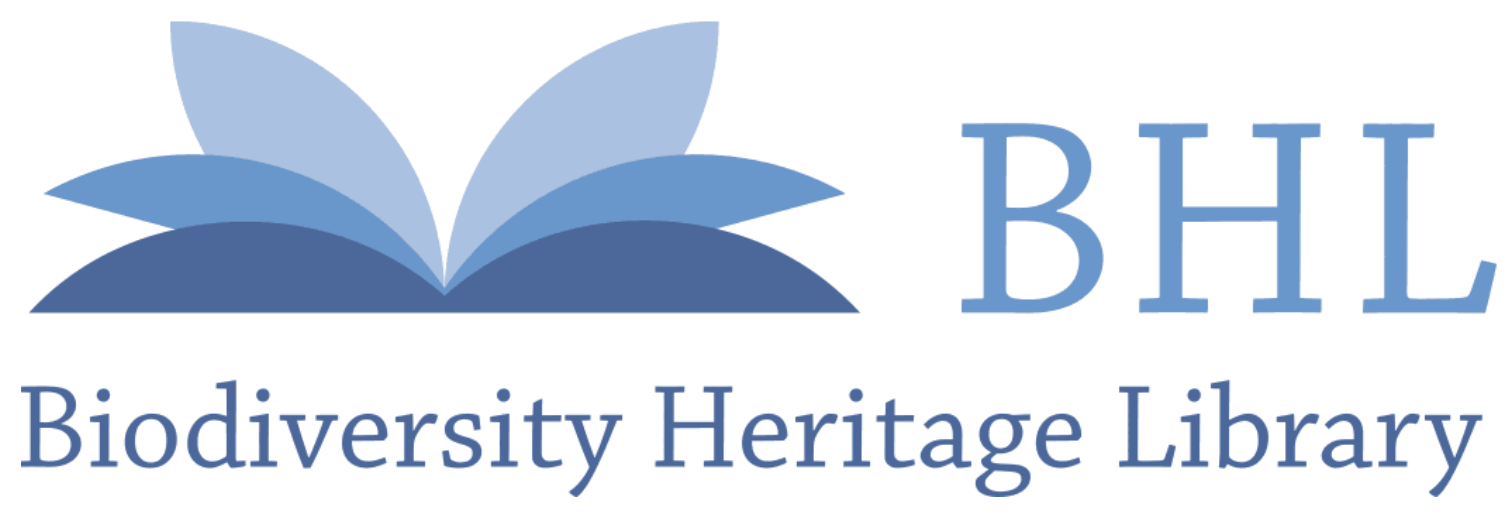

1909. "Two new species of Coccinellidae (Coleoptera)." Entomological news, and proceedings of the Entomological Section of the Academy of Natural Sciences of Philadelphia 20, 161-162.

View This Item Online: https://www.biodiversitylibrary.org/item/20250

Permalink: https://www.biodiversitylibrary.org/partpdf/23110

\section{Holding Institution}

Smithsonian Libraries

\section{Sponsored by}

Smithsonian

\section{Copyright \& Reuse}

Copyright Status: NOT_IN_COPYRIGHT

This document was created from content at the Biodiversity Heritage Library, the world's largest open access digital library for biodiversity literature and archives. Visit BHL at https://www.biodiversitylibrary.org. 